\title{
The Development of Thermal Coefficients of Photovoltaic Devices
}

\author{
Stefan Mitterhofer, Boštjan Glažar, Marko Jankovec, Marko Topič
}

University of Ljubljana, Faculty of Electrical Engineering, Laboratory of Photovoltaics and Optoelectronics, Ljubljana, Slovenia

\begin{abstract}
Photovoltaic modules installed in the field exhibit a wide range of operating temperatures, depending on the meteorological and environmental conditions. Their temperature influences their output power and conversion efficiency. Temperature dependence is typically described as a linear function with the temperature coefficients of open-circuit voltage, shortcircuit current and maximal output power. To analyse the development of these parameters over time, the data of modules of several technologies is evaluated, monitored from five to eight years at our outdoor test site. The measurement data is cleaned of outliers and systematic measurement errors and then translated to the irradiance of $1000 \mathrm{~W} / \mathrm{m} 2$ at standard test conditions. Several discrepancies compared to the datasheet values of the photovoltaic modules are found. These discrepancies are attributed to the parameters' sensitivity to other factors, mostly pronounced in the short-circuit current. One such factor is the spectrum of the incident light. The temperature coefficients are then analysed each month to evaluate their development over time. A seasonality is found, showing a higher temperature sensitivity of the short-circuit current in the winter and a correspondingly lower sensitivity of the output power at maximum power point. However, no systematical change over time due to possible influences of module degradation in the timeframe of up to eight years was observed.
\end{abstract}

Keywords: photovoltaics; thermal coefficients; performance monitoring

\section{Dolgoročna odvisnost temperaturnih koeficientov fotonapetostnih modulov}

\begin{abstract}
Izvleček: Fotonapetostni moduli v času obratovanja doživijo širok razpon obratovalnih temperatur glede na pogoje okolice, kjer so nameščeni. Temperatura celic, katere vpliv opisujemo s temperaturnimi koeficienti napetosti odprtih sponk, kratkostičnega toka in maksimalne moči, vpliva na njihovo zmogljivost in učinkovitost. V članku smo analizirali dolgoročne poteke temperaturnih koeficientov fotonapetostnih modulov različnih tehnologij, ki jih dolgoročno spremljamo na našem testnem poligonu od pet do osem let. Merilne rezultate smo preračunali na standardno obsevanje $1000 \mathrm{~W} / \mathrm{m} 2$ in izločili izstopajoče meritve in sistematične merilne napake. Opazili smo razlike v primerjavi z vrednostmi temperaturnih koeficientov, ki jih navajajo proizvajalci. Razlike so najbolj izrazite pri kratkostičnem toku in jih pripisujemo občutljivosti parametrov na druge dejavnike, kot npr. spekter vpadne svetlobe. Temperaturne koeficiente smo analizirali na mesečni ravni, da smo ocenili njihovo časovno spreminjanje. V rezultatih so najbolj razvidni sezonski vplivi, kjer je pozimi temperaturni koeficient kratkostičnega toka višji in posledično maksimalne moči ustrezno nižji. Vendar pa ni bilo opaziti sistematične časovne spremembe zaradi možnih vplivov degradacije fotonapetostnega modula.
\end{abstract}

Ključne besede: fotovoltaika; temperaturni koeficienti; spremljanje učinkovitosti

*Corresponding Author's e-mail: stefan.mitterhofer@fe.uni-lj.si

\section{Introduction}

Photovoltaic (PV) devices convert energy emitted from the sun or other light sources directly into electrical energy. Incident photons excite electrons from the valence band into the conduction band of a semiconductor, creating electron-hole pairs that generate voltage and current at the contacts in a well know current- voltage (IV) characteristic under illumination [1]. A depiction of an IV curve of a PV cell is shown in Figure 1. The most important parameters describing the device's performance are the short-circuit current $I_{S C^{\prime}}$ the open-circuit voltage $\mathrm{V}_{\mathrm{OC}}$ and the fill factor $\mathrm{FF} . \mathrm{I}_{\mathrm{SC}}$ is the current through the cell, when it is short circuited and the voltage across the cell is zero. $\mathrm{v}_{\mathrm{oc}}$ is the maximum 
possible voltage across the cell at zero current. The power output $\mathrm{P}$ of a PV cell is given as the product of voltage and current. The maximum power output $P_{M P P}$ is achieved at the maximum power point (MPP), with the corresponding voltage $V_{M P P}$ and current $I_{M P P}$. The fill factor FF of a solar cell is the ratio between the $P_{\text {MPP }}$ and the product of $\mathrm{I}_{\mathrm{SC}}$ and $\mathrm{V}_{\mathrm{OC}}$. It is the ratio between the areas of yellow and blue rectangles in Figure 1.

$F F=\frac{U_{M P P} \cdot I_{M P P}}{V_{O C} \cdot I_{S C}}$

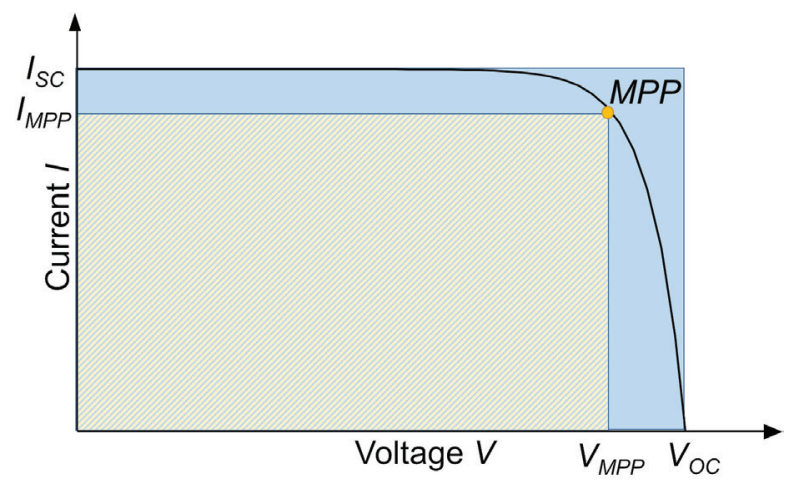

Figure 1: IV curve of a PV cell.

\subsection{Loss mechanisms in PV devices}

The efficiency of this energy conversion process in an idealized case is limited by several fundamental loss mechanisms. The first approach to calculate this limit for single-junction solar cells was taken by Shockley and Queisser using the detailed balance principle [2]. It is therefore referred to as Shockley-Queisser limit. Similar results were later obtained using a thermodynamic approach [3]. More recent work yielded the same results analyzing the impact of single intrinsic loss processes [4]. These loss mechanisms are:

- $\quad$ Thermalisation: Photons with an energy $E$ above the semiconductor bandgap Eg quickly lose this energy and fall down to the conduction band. This process is usually many orders of magnitude faster than charge carrier extraction [5].

- $\quad$ Below Eg: Photons with E < Eg are generally not absorbed and do not create an electron-hole pair.

- $\quad$ Emission:The PV device emits photons according to the generalized Planck equation [6], [7].

Boltzmann or angle mismatch: Entropy is generated and the corresponding energy lost. This process is linked to an angle mismatch between incident and emitted photons.

- $\quad$ Carnot: As an energy converter, the solar cell is limited by the Carnot efficiency. The sun is the hot reservoir, the cell is the cold one.
There are several ways to reduce their impact and achieve efficiencies above the Shockley-Queisser limit, for example multi-junction cells [6], intermediate band cells [8] or concentrating sunlight [9]. However, these losses are unavoidable in single-junction devices.

Additional loss mechanisms in real world devices reduce the efficiency further. Thus, the conversion efficiency $\eta$ of even the best laboratory single-junction solar cells is a few percent below the Shockley-Queisser limit [10]. These additional loss mechanisms are:

- $\quad$ Non radiative recombination: Shockley-Read-Hall [11], [12], Auger [13] and surface recombination.

- $\quad$ Optical losses: Reflection on material interfaces, transmission of photons with energy $\mathrm{E}>\mathrm{Eg}$.

- Parasitic resistances: A series resistance within the cell, in metal contacts and on the interface can cause further losses. A shunt resistance in the device can create alternative current pathways. This is commonly connected to manufacturing defects or cell degradation [14].

- $\quad$ Parasitic absorption: Absorption of photons with $E>E g$, which do not result in the creation of charge carriers.

\subsection{Temperature sensitivity of PV cell parameters}

Because all fundamental and several additional loss mechanisms depend on the device temperature $T$, the output of PV modules and their efficiency is a function of T. The temperature coefficients analysed are usually the coefficient $\alpha$ of the short-circuit current density $\mathrm{J}_{\mathrm{SC}^{\prime}}$ the coefficient $\beta$ of the open-circuit voltage $V_{o c}$ and the coefficient $\gamma$ of the output power $\mathrm{P}_{\text {MPP }}$ at the MPP.

The major part of the overall temperature sensitivity of solar cells is caused by the coefficient $\beta$ [15]. At VOC, generation equals recombination, and the current density is zero. $\beta$ is therefore an indication of the temperature dependence of the generation-recombination balance. It is [15-17]:

$\beta=\frac{1}{V_{O C}} \frac{d V_{O C}}{d T}=-\frac{1}{V_{O C}} \frac{\frac{E_{g 0}}{q}-V_{O C}+\frac{k T}{q} \gamma \frac{f}{\xi} \frac{d \xi}{d f}}{T}$.

Here, $n$ is the diode ideality factor, $k$ the Boltzmann constant and $q$ the elementary charge. The function $f$ describes individual recombination processes dependent on $\xi$. This parameter is introduced for mathematical convenience and depends on the intrinsic, electron and hole carrier concentrations, as well as Eg and T.

The coefficient $\alpha$ is [15]: 
$\beta=\frac{1}{J_{S C}} \frac{d J_{S C}}{d T}=\frac{1}{J_{S C, \text { ideal }}} \frac{d J_{S C, \text { ideal }}}{d E_{g}} \frac{d E_{g}}{d T}+\frac{1}{f_{c}} \frac{d f_{C}}{d T}$.

Here, $\mathrm{J}_{\text {scideal }}$ is an ideal short-circuit current density, only dependent on the incident photon flux and disregarding loss mechanisms. $f_{c}$ is a collection factor describing the impact of these loss mechanisms. There are various issues with an accurate determination of a [16-18]. It depends on the incident light intensity and spectrum. However, solar simulators used to determine the electrical characteristics of PV modules are classified by integrating their total irradiance over several broad parts of the spectrum and comparing them individually to the AM1.5 spectrum [19]. Thus, the spectral radiance of such solar simulators can exhibit variations between each other, and compared to the AM1.5 spectrum [20]. Correspondingly, the determined values of a can show large variations [21], [22]. The incident spectrum in the field also changes depending on time and location of the PV installation, leading to similar discrepancies. Another issue are the temperature differences between single cells of a module, which can lead to further inaccuracies of the determination of $\alpha$ [23], [24].

There is no similar equation for the coefficient $y$ available in literature. It is dependent on the other temperature coefficients, as well as on the temperature coefficient of the fill factor FF, since:

$P_{M P P}=I_{S C} \cdot V_{O C} \cdot F F$.

An analysis of the latter is given in [25], resulting in:

$$
\begin{aligned}
\frac{1}{F F} \frac{d F F}{d T} & \approx\left(1-1.02 F F_{0}\right)\left(\frac{1}{V_{O C}} \frac{d V_{O C}}{d T}-\frac{1}{T}\right) \\
& -\frac{R_{s}}{V_{O C} / I_{S C}-R_{s}}\left(\frac{1}{R_{s}} \frac{d R_{s}}{d T}\right)
\end{aligned}
$$

Here, $\mathrm{FF}_{0}$ is an approximation of the fill factor neglecting series resistance $R_{s}$ and shunt resistance, and assuming a one-diode model with diode ideality factor $n$, given in equation (6) [26].

$$
\begin{aligned}
& F F_{0}=\frac{v_{O C}-\ln \left(v_{O C}+0.72\right)}{v_{O C}+1} \\
& v_{O C}=\frac{q}{n k T_{C}} V_{O C}
\end{aligned}
$$

However, equation (5) only accounts for the series resistance, and neglects the impact of the shunt resistance and the diode ideality factor on the temperature coefficient. A corresponding evaluation including all these factors is still missing in literature. Thus, it is not surprising that large variations between experimental values and calculations were found [18].

\subsection{PV modules in the field}

Many models have been developed to predict the temperature of PV modules in the field, as reviewed in [27]. It is dependent on climatic factors, for example ambient temperature, irradiance and wind speed, but also technological factors, for example type of module and mounting configuration. Depending on these factors, $T$ shows large variations at different times at different locations. Thus, the total yield of PV installations strongly depends on their temperature sensitivity. Module datasheets therefore commonly contain one value for each of the three temperature coefficients $\alpha, \beta$ and $\gamma$. They are usually obtained with the methods defined in the IEC 60891 standard [28]. This standard requires multiple measurements within a range of at least $30^{\circ} \mathrm{C}$ at a single irradiance. The results are valid at $\pm 30 \%$ of this irradiance. Datasheets usually give the values under standard test condition (STC) irradiance: the AM1.5 spectrum at $1000 \mathrm{~W} / \mathrm{m}^{2}$. They rarely include an error range of these values, or values for multiple irradiances. Note that another standard exists containing a more in-depth evaluation at different irradiances and temperatures, the IEC 61853-1 [29].

PV modules are expected to last for $25+$ years in the field. Their STC output power degrades usually between $0.5 \%$ and $1 \%$ annually, varying between PV technologies, climate and installation conditions [30]. This degradation is caused by various degradation modes, affecting the PV modules differently [31]. The thermal coefficients are assumed to be stable and unaffected by these degradation modes. However, a recent analysis of field-aged PV modules has shown the inadequacy of this assumption for $\gamma$ [32]. Thus, the development of the temperature coefficients over time has to be considered for an accurate lifetime analysis and yield estimation of a PV system. According to the best of our knowledge, no such analysis has been published yet.

In this paper, we propose and carry out such an analysis. Chapter 2 presents the PV test site, containing modules of various technologies installed for several years, and the methods used to evaluate the measured data. Chapter 3 gives the results of the data analysis. Chapter 4 contains a discussion of the results. 


\section{Methods}

\subsection{Measurements}

The data is taken from the PV test site of the Laboratory of Photovoltaics and Optoelectronics (LPVO) [33] as well as the adjacent PV power plant on the roof of the Faculty of Electrical Engineering, University of Ljubljana in Ljubljana, Slovenia, shown in Figure 2. The analysed period is between five and eight years, depending on the time the corresponding module was installed.

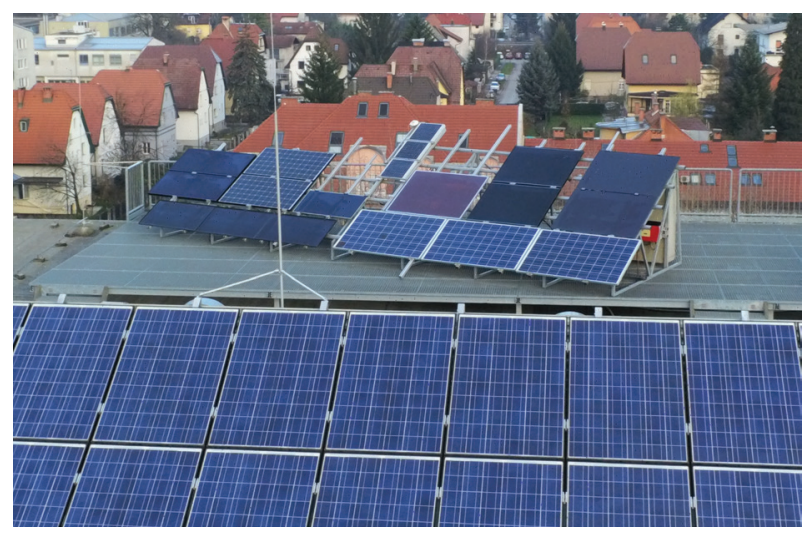

Figure 2: Monitored PV test site and adjacent PV power plant in Ljubljana, Slovenia.

Modules of various PV technologies, including amorphous silicon (a-Si), Cadmium-Tellurite (CdTe), CopperIndium-Gallium-Selenide (CIGS), micromorph silicon $(\mu-\mathrm{Si})$, poly- and mono-crystalline silicon (c-Si) are monitored. One measurement is taken every 10 minutes and contains $\mathrm{T}$, short-circuit current $\mathrm{I}_{\mathrm{SC}}, \mathrm{V}_{\mathrm{OC}}$ and $\mathrm{P}_{\mathrm{MPP}}$ of the modules, as well as the irradiance G. The temperature is measured on the backside of every module with an attached Dallas DS18B20 digital temperature sensor. The irradiance in plane of array is measured with a Kippen-Zonen CMP21 pyranometer on the test site. The output of the modules is measured with a module monitoring system [33]. They are stored in a database along with further measurements (IV curve, $F F, R_{s^{\prime}}$ etc.), which are however not used in this analysis. Between the measurements, modules are kept in their respective MPP. Additionally, the spectral irradiance is measured with an EKO MS-711 spectroradiometer.

\subsection{Data cleaning}

The data is extracted from the database using Python 3.6.5. It is then translated to STC irradiance of $1000 \mathrm{~W} /$ $\mathrm{m}^{2}$ to remove the dependency of $\mathrm{I}_{\mathrm{SC}^{\prime}}, \mathrm{V}_{\mathrm{OC}}$ and $\mathrm{P}_{\mathrm{MPP}}$ on the irradiance. There are various possibilities for such a translation, which are generally empirical formulas approximating the real behavior. Thus, a small error depending on the difference of the irradiance to STC conditions is expected. Several possible translation formulas are reviewed for the single-diode model in [34]. The formulas used here are:

$$
\begin{aligned}
& I_{S C, S T C}=\frac{G_{S T C}}{G} \cdot I_{S C}(G) \\
& V_{O C, S T C}=V_{O C}(G)-\frac{N_{S} k T n}{q} \ln \left(\frac{G}{G_{S T C}}\right) \\
& P_{M P P, S T C}=\frac{G_{S T C}}{G} \cdot P_{M p p}(G)
\end{aligned}
$$

Here, $\mathrm{N}_{\mathrm{s}}$ the number of cells in one string. It is obtained from the corresponding datasheets or, if missing, counted on the modules. For simplicity, $\mathrm{n}$ is set to 1 . The index STC denotes the translated values. An example of this translation is shown in Figure 3 and Figure 4 for the $\mathrm{I}_{\mathrm{sC}}$ of a crystalline silicon module.

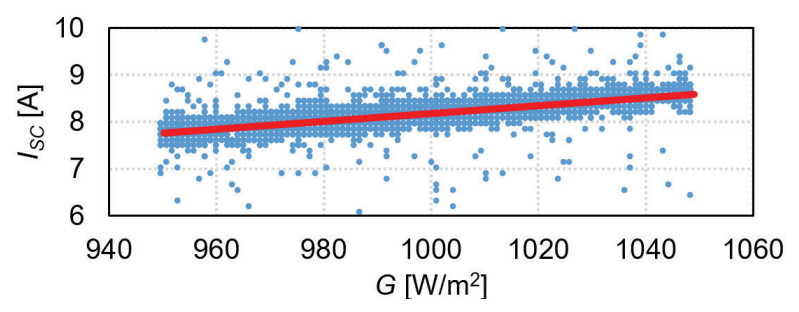

Figure 3: $I_{S C}$ before translation to STC irradiance. The red curve shows the trendline of the data.

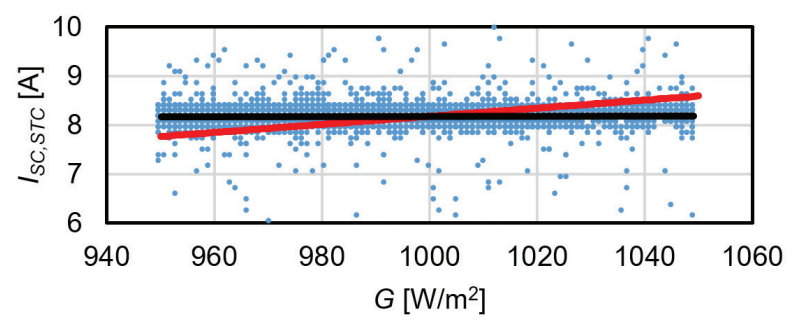

Figure 4: $I_{S C}$ after translation to STC irradiance. The black curve shows the trendline of the data, showing it is independent of the irradiance. The red curve, for comparison, shows the trendline of the data before translation (same as in Figure 3).

The data is then filtered. Over the range of several years, the measurement setup proved to be very stable and provide high quality data. However, several statistical and systematic measurement errors occurred. In a first filtering step, the raw data is analysed to identify the systematic errors. Several periods had to be excluded due to faulty measurements.

One example of such an error can be found evaluating $\mathrm{I}_{\mathrm{SCSTC}}$. The values during July - October 2016 are offset compared to all others, shown in Figure 5. The rea- 
son was determined to be problems of the irradiance measurements in that period.

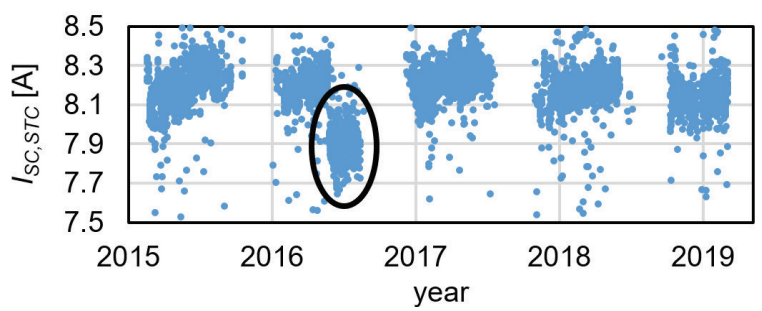

Figure 5: An example of a systematic measurement error. A further analysis of the highlighted data showed, that the irradiance measurements during this time were incorrect.

However, some cases prove more difficult to include, for example degradation. It is usually a gradual process. To filter the data in such cases is a trade-off between a shorter analysed period and accordingly fewer measurements on the one hand. This reduces the statistical significance and can lead to an increase of seasonal effects, skewing the data. On the other hand, a longer time frame increases the impact of degradation on the results. An example is shown in Figure 6, where a gradual degradation of the $\mathrm{V}_{\text {oc }}$ in a CIGS module can be observed. It was especially pronounced in the first year the module was installed at the test site.

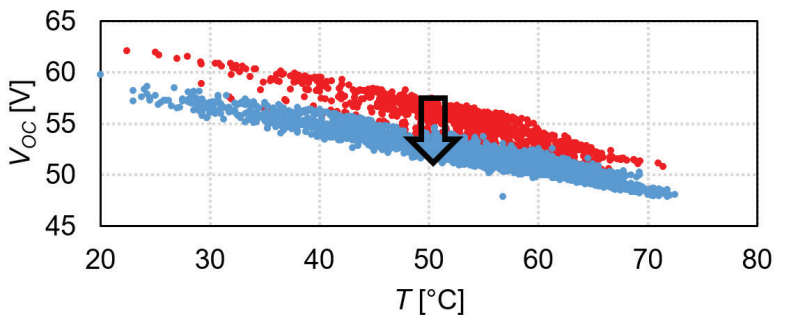

Figure 6: Gradual degradation of $\mathrm{V}_{\mathrm{OC}}$ over time. The arrow shows the trend of the development over time. The red points mark data from the first year after installation (10.2014 - 10.2015), the blue points from the following years.

In a second filtering step, the statistical outliers of the measurements are removed. For this purpose, a linear regression over the data is carried out using the linear regression model of the scipy.stats module in Python. The results are used to remove outliers above three standard deviations in $\mathrm{V}_{\mathrm{OC}}$ and two in $\mathrm{I}_{\mathrm{SC}}$ and $\mathrm{P}_{\mathrm{MPP}}$. Generally $\mathrm{I}_{\mathrm{SC}}$ and $P_{\text {MPP }}$ show far more outliers, requiring the lower threshold to clean the data. An example is shown in Figure 7.

\subsection{Data analysis}

The cleaned data is then analysed more in-depth. In the first analysis, the temperature coefficients of the modules are extracted over the entire timespan using a linear regression on the cleaned data. Measurements

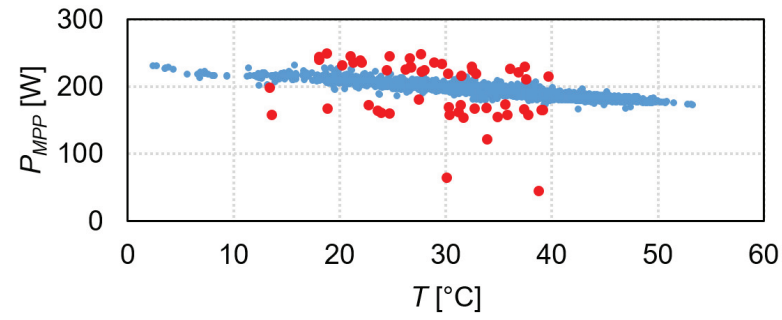

Figure 7: Removed statistical outliers (red).

taken with an irradiance between $950 \mathrm{~W} / \mathrm{m}^{2}$ and 1050 $\mathrm{W} / \mathrm{m}^{2}$ are analysed. Additional evaluations using larger irradiance ranges are carried out to evaluate the sensitivity of the results to this filter. Each step, the minimum irradiance considered is reduced by $50 \mathrm{~W} / \mathrm{m}^{2}$ and the maximum irradiance increased by the same amount. In the case of a very strong degradation over a short timespan, for example as shown in Figure 6, the data is not considered in this evaluation.

In the second analysis, the monthly coefficients are extracted using a linear regression on monthly data. This approach enables the evaluation of the development of the thermal coefficients over time by comparing them during the same month over several years. Some sources of inaccuracies of the determination of these coefficients described in the introduction are thus minimized. Furthermore, possible seasonal variations of these coefficients over a year can be analysed.

Three different approaches for the choice of the analysed irradiance range are taken. The corresponding results are compared and the impact of the used irradiance filter analysed. In the first approach, the range is set to $500 \mathrm{~W} /$ $\mathrm{m}^{2}-1200 \mathrm{~W} / \mathrm{m}^{2}$. Using these values, in the winter on average $\sim 100$ measurements each month are available. Most of them are close to the lower limit in this range. However, many more measurements are available at higher irradiances in the summer. Thus, in the second approach only measurements with an irradiance between $500 \mathrm{~W} / \mathrm{m}^{2}$ and $700 \mathrm{~W} / \mathrm{m}^{2}$ are considered. In the third approach, different filters are chosen during different months of the year. The settings are summarized in Table 1. The chosen irradiance filters ensure, that most measurements are obtained under a clear-sky condition. Approximately 100 measurements or more each month are available using these filters, depending on the weather and filtered out periods due to systematic measurement errors.

Table 1: Irradiance filters used

\begin{tabular}{|l|c|c|}
\hline Months & $\mathrm{G}_{\min }\left[\mathrm{W} / \mathrm{m}^{2}\right]$ & $\mathrm{G}_{\text {mix }}\left[\mathrm{W} / \mathrm{m}^{2}\right]$ \\
\hline May - August & 800 & 1200 \\
\hline $\begin{array}{l}\text { March, April, September, } \\
\text { October }\end{array}$ & 700 & 1200 \\
\hline November - February & 500 & 1200 \\
\hline
\end{tabular}


Narrower ranges would reduce the amount of measurements, reducing the statistical significance and yield a worse result from the linear regression. Wider ranges would increase the variation of conditions, under which the measurements are taken. This leads to a larger spread of data and correspondingly a larger error margin of the fit. In certain conditions, this could even lead to a systematic error of the determined coefficient. All irradiance filters given here are thus chosen carefully. They are specific to the location of the analysed modules and should not be taken as a general guideline.

Because the spectral irradiance has shown to influence $a$, it is analysed and compared in different conditions. The first analysis compares the spectra in the winter and summer at a similar total irradiance. The second analysis evaluates differences in the spectrum during the summer with similar total irradiance, but at different times and conditions: clear sky condition in the early morning and in the evening as well as cloudy sky condition at noon.

\section{Results}

\subsection{Analysis of temperature coefficients}

The results of the analysis over the entire measured timespan are given in Table 2. Several discrepancies between the results and the corresponding datasheet values can be observed. The obtained values of a show on average the largest differences from the datasheet. They are suspected to stem from the high sensitivity of $I_{S C}$ to various environmental parameters and the corresponding issues of determining a accurately described in the introduction. Next to the differences between the experimental results and the datasheet, this sensitivity causes a large spread of the data. The corresponding fit can show a large error margin, even after the rigorous data filtering. Figure 8 and Figure 9 show examples of a good fit, commonly observed with $\mathrm{V}_{\mathrm{OC}}$, and a bad fit, commonly observed with $\mathrm{I}_{\mathrm{SC}}$ and $\mathrm{P}_{\mathrm{MPP}}$ Extending the analysed irradiance range increases the temperature coefficients of most modules. A reason for this behavior was not found.

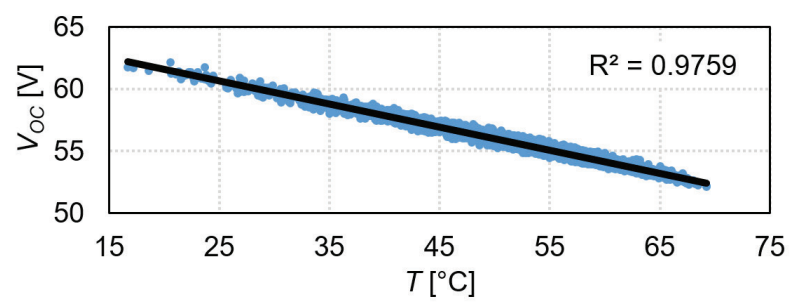

Figure 8: Example of a good fit and clean data.

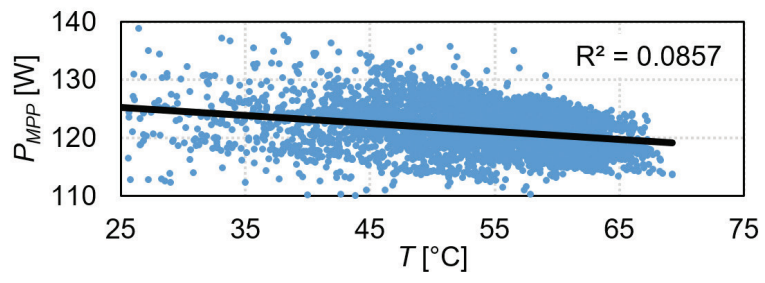

Figure 9: Example of a large data spread and a correspondingly bad fit.

Another interesting result is the positive value of $\gamma$ for the a-Si module. It is connected to the large increase in $\mathrm{I}_{\mathrm{SC}}$ with increasing temperature, as well as an increase of the fill factor. This effect has been reported before and is connected to lower resistance effects and decreased recombination [15], [35]. Note that this module's datasheet contains a negative value of $\gamma$. A possible reason for this discrepancy, next to the issues with an accurate determination of $\mathrm{I}_{\mathrm{SC}^{\prime}}$ is the thermal history of the modules. In thin film devices, this history has shown to in-

Table 2: The temperature coefficients of several modules obtained from the analysis using the $950 \mathrm{~W} / \mathrm{m}^{2}-1050 \mathrm{~W} /$ $\mathrm{m}^{2}$ filter, and from the corresponding datasheets. The error margins given are obtained from the scipy.stats module in Python and, in the case of multiple modules, calculated.

\begin{tabular}{|l|c|c|c|c|c|c|c|}
\multirow{2}{*}{ Module type } & \multirow{2}{*}{$\#$} & \multicolumn{2}{|c|}{$\mathrm{\alpha}\left[\% /{ }^{\circ} \mathrm{C}\right]$} & \multicolumn{2}{c|}{$\beta\left[\% /{ }^{\circ} \mathrm{C}\right]$} & \multicolumn{2}{c|}{$\gamma\left[\% /{ }^{\circ} \mathrm{C}\right]$} \\
\cline { 3 - 8 } & & calculated & datasheet & calculated & datasheet & calculated & datasheet \\
\hline Poly c-Si & 1 & $0.15 \pm 0.01$ & $6 \cdot 10-4$ & $-0.31 \pm 0.01$ & -0.32 & $-0.45 \pm 0.01$ & -0.40 \\
\hline Poly c-Si & 3 & $0.02 \pm 0.01$ & $\mathrm{n} / \mathrm{a}$ & $-0.32 \pm 0.01$ & $\mathrm{n} / \mathrm{a}$ & $-0.47 \pm 0.02$ & $\mathrm{n} / \mathrm{a}$ \\
\hline $\mathrm{CIGS}$ & 2 & $-0.06 \pm 0.01$ & 0.03 & $-0.36 \pm 0.01$ & -0.28 & $-0.49 \pm 0.01$ & -0.39 \\
\hline $\mathrm{CIGS}$ & 2 & $0.02 \pm 0.01$ & 0.01 & $-0.25 \pm 0.01$ & -0.30 & $-0.33 \pm 0.01$ & -0.31 \\
\hline $\mathrm{CIGS}$ & 3 & $0.12 \pm 0.02$ & 0.04 & $-0.23 \pm 0.07$ & -0.26 & $-0.14 \pm 0.18$ & -0.30 \\
\hline $\mathrm{CdTe}$ & 1 & $0.11 \pm 0.01$ & 0.04 & $-0.23 \pm 0.01$ & -0.27 & $-0.16 \pm 0.01$ & -0.25 \\
\hline $\mathrm{a}-\mathrm{Si}$ & 1 & $0.25 \pm 0.01$ & 0.09 & $-0.29 \pm 0.01$ & -0.33 & $0.03 \pm 0.01$ & -0.20 \\
\hline$\mu$-Si & 2 & $0.15 \pm 0.03$ & 0.07 & $-0.30 \pm 0.01$ & -0.30 & $-0.11 \pm 0.01$ & -0.24 \\
\hline Mono c-Si (HIT) & 2 & $-0.01 \pm 0.01$ & $3 \cdot 10-4$ & $-0.24 \pm 0.01$ & -0.25 & $-0.31 \pm 0.01$ & -0.29 \\
\hline
\end{tabular}


fluence the obtained values of the temperature coefficients. Thus, the corresponding standard specifies that the history concerning the irradiation and the thermal history have to be indicated in a report presenting the measurements of these coefficients in a laboratory setting [28].

\subsection{Change of the temperature coefficients over time}

Using a single irradiance filter during the entire year leads to a large spread of the data and a correspondingly larger error margin of the coefficients. The spectral irradiance analysis shows, that the chosen irradiance filters contain different incident spectra. While these differences are only in the range of a few percent at various wavelengths, they are suspected to be one of the reasons for the large error margins. Reducing the size of the analysed irradiance range to reduce these inaccuracies would remove almost all measurements in the winter.

Thus, the third approach described in chapter 2.3 using different irradiance filters during the year yields the best results. The resulting thermal coefficients show no systematic changes during the analysed period. An example of a CIGS module is shown in Figure 10. However, they show large seasonal variations. There are various possible reasons for this behavior. Non-linear effects of the irradiance translation become more apparent for larger differences to the STC irradiance. Furthermore, different thermal coefficients at various temperatures are possible. Only a single datasheet of the analysed modules contains a second value for $\beta$. It is higher at lower temperatures, which is in line with the results found in this study.
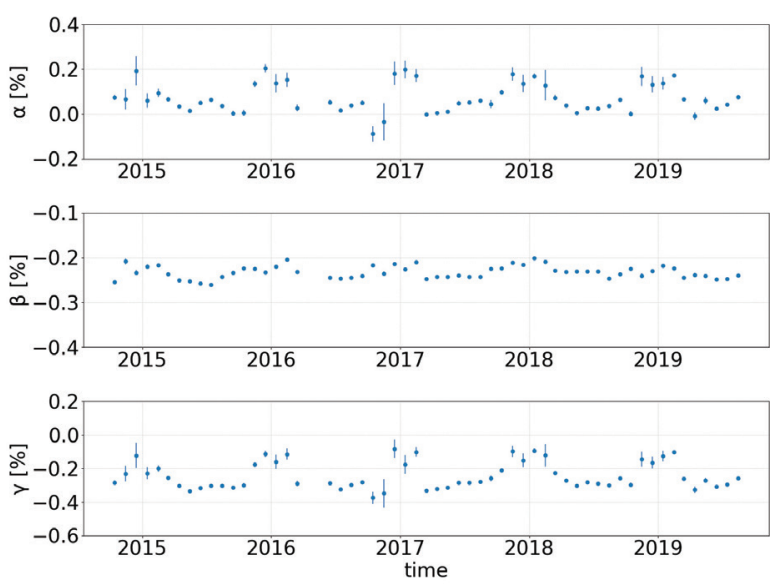

Figure 10: Development of the temperature coefficients of a CIGS module over time. The lines show the standard error obtained from the scipy.stats Python module.

\section{Discussion}

Open-circuit voltage $\mathrm{V}_{\mathrm{oc}}$ is, in general, the strongest varying factor with a change in temperature. This is in line with the literature presented in the introduction. The generation-recombination balance is, of all the processes influencing the power extracted from the module, the most sensitive to a temperature change. Furthermore, the results show a small spread of the data and a reasonably good fit with the data sheet values, showing a comparably low dependency on other climatic parameters.

Short-circuit current generally increases with increasing temperature. This is caused by a higher collection efficiency at higher temperatures [17]. The measured data exhibits a large spread, leading to possible inaccuracies of the fitting process. This is as well in agreement with literature, emphasizing the high sensitivity of the short-circuit current to outside influences besides the temperature. Thus, a narrow irradiance filter is required for an accurate determination of $\alpha$, as long as enough measurements are available using this filter.

The same issues cause a large inaccuracy in the determination of $\gamma$. The calculated values differ from the datasheet for several modules. These problems to determine $\alpha$ and $\gamma$ accurately, and their dependence on other environmental parameters, show that a single value obtained in a laboratory according to IEC 60891 cannot be taken for an accurate prediction of module behavior in the field. Similarly, an extrapolation of such behavior from one climate and location to another can prove difficult and is endowed with a certain inaccuracy. The multiple values at different temperatures and irradiances defined in IEC 61853-1 would serve as a much better basis of such a prediction.

The modules at the test site will be monitored further. The methodology presented in this paper can be applied to larger systems and modules installed in different climates for a better statistical analysis of the development of the temperature coefficients, as well as their correlation to other parameters.

\section{Conclusions}

The temperature coefficients of the analysed photovoltaic modules do not change in the installed climate over several years. They exhibit a seasonal variation, which can be linked to larger errors stemming from the translation of the measurements to STC irradiance, as well as the sensitivity of these parameters to other factors. Examples include the spectrum of the incident 
light, the temperature and temperature variations between the cells inside a module. These results emphasize the requirement of a more in-depth evaluation of these parameters for an accurate lifetime and yield analysis of PV modules installed in different locations in the field.

\section{Acknowledgments}

This project has received funding from the European Union's Horizon 2020 programme in the framework of the project "SolarTrain" under GA No. 721452 and the Slovenian Research Agency under the research programme P2-0197. The authors thank Kristijan Brecl, Matevž Bokalič and Julian Ascencio-Vazquez, University of Ljubljana, for useful discussion.

\section{Conflict of Interest}

The authors declare no conflict of interest.

\section{References}

1. M. A. Green, Solar cells: operating principles, technology, and system applications. Englewood Cliffs, NJ: Prentice-Hall, 1982.

2. W. Shockley and H. J. Queisser, 'Detailed Balance Limit of Efficiency of p-n Junction Solar Cells', Journal of Applied Physics, vol. 32, no. 3, pp. 510519, Mar. 1961, https://doi.org/10.1063/1.1736034.

3. R. T. Ross, 'Some Thermodynamics of Photochemical Systems', The Journal of Chemical Physics, vol. 46 , no. 12 , pp. 4590-4593, Jun. 1967, https://doi.org/10.1063/1.1840606.

4. L. C. Hirst and N. J. Ekins-Daukes, 'Fundamental losses in solar cells', Progress in Photovoltaics: Research and Applications, vol. 19, no. 3, pp. 286293, May 2011, https://doi.org/10.1002/pip.1024.

5. P. Würfel and U. Würfel, Physics of solar cells: from basic principles to advanced concepts, 2 nd, updated and expanded ed ed. Weinheim: Wiley$\mathrm{VCH}, 2009$.

6. C. H. Henry, 'Limiting efficiencies of ideal single and multiple energy gap terrestrial solar cells', Journal of Applied Physics, vol. 51, no. 8, pp. 4494-4500, Aug. 1980,

https://doi.org/10.1063/1.328272.

7. W. Ruppel and P. Wurfel, 'Upper limit for the conversion of solar energy', IEEE Transactions on
Electron Devices, vol. 27, no. 4, pp. 877-882, Apr. 1980,

https://doi.org/10.1109/T-ED.1980.19950.

8. A. Luque and A. Martí, 'Increasing the Efficiency of Ideal Solar Cells by Photon Induced Transitions at Intermediate Levels', Physical Review Letters, vol. 78, no. 26, pp. 5014-5017, Jun. 1997, https://doi.org/10.1103/PhysRevLett.78.5014.

9. W. H. Press, 'Theoretical maximum for energy from direct and diffuse sunlight', Nature, vol. 264, no. 5588 , p. 734 , Dec. 1976 , https://doi.org/10.1038/264734a0.

10. M. A. Green et al., 'Solar cell efficiency tables (Version 53)', Progress in Photovoltaics: Research and Applications, vol. 27, no. 1, pp. 3-12, Jan. 2019, https://doi.org/10.1002/pip.3102.

11. W. Shockley and W. T. Read, 'Statistics of the Recombinations of Holes and Electrons', Physical Review, vol. 87, no. 5, pp. 835-842, Sep. 1952, https://doi.org/10.1103/PhysRev.87.835.

12. R. N. Hall, 'Electron-Hole Recombination in Germanium', Physical Review, vol. 87, no. 2, pp. 387387, Jul. 1952, https://doi.org/10.1103/PhysRev.87.387.

13. P. V. Auger, 'Sur les rayons $\beta$ secondaires produits dans un gaz par des rayons X', C.R.A.S., vol. 177, pp. 169-171, 1923.

14. V. Naumann et al., 'Explanation of potential-induced degradation of the shunting type by $\mathrm{Na}$ decoration of stacking faults in Si solar cells', Solar Energy Materials and Solar Cells, vol. 120, pp. 383-389, Jan. 2014, https://doi.org/10.1016/j.solmat.2013.06.015.

15. M. A. Green, 'General temperature dependence of solar cell performance and implications for device modelling', Progress in Photovoltaics: Research and Applications, vol. 11, no. 5, pp. 333-340, Aug. 2003, https://doi.org/10.1002/pip.496.

16. O. Dupré, R. Vaillon, and M. A. Green, Thermal Behavior of Photovoltaic Devices. Cham: Springer International Publishing, 2017.

17. O. Dupré, R. Vaillon, and M. A. Green, 'Physics of the temperature coefficients of solar cells', Solar Energy Materials and Solar Cells, vol. 140, pp. 92100, Sep. 2015, https://doi.org/10.1016/j.solmat.2015.03.025.

18. O. Dupre, R. Vaillon, and M. A. Green, 'Experimental Assessment of Temperature Coefficient Theories for Silicon Solar Cells', IEEE Journal of Photovoltaics, vol. 6, no. 1, pp. 56-60, Jan. 2016, https://doi.org/10.1109/JPHOTOV.2015.2489864.

19. International Electrotechnical Commission, 'IEC 60904-9:2007 - Photovoltaic devices - Part 9: Solar simulator performance requirements', International Standard, 2007. 
20. G. Leary, G. Switzer, G. Kuntz, and T. Kaiser, 'Comparison of xenon lamp-based and led-based solar simulators', in 2016 IEEE 43rd Photovoltaic Specialists Conference (PVSC), Portland, OR, USA, 2016, pp. 3062-3067, https://doi.org/10.1109/PVSC.2016.7750227.

21. G. Landis, 'Solar Cell Temperature Coefficients', presented at the SPRAT 13, Washington, DC, 1994, p. 16.

22. J. H. Fatehi, C. Kedir, C. Tumengko, J. L. R. Watts, and N. Riedel, 'Results from flash testing at multiple irradiances and temperatures across five photovoltaic testing labs', in 3rd PV Performance Modeling Workshop, Santa Clara, CA, 2014, https://doi.org/10.13140/rg.2.2.21370.24007.

23. C. R. Osterwald, M. Campanelli, G. J. Kelly, and R. Williams, 'On the reliability of photovoltaic shortcircuit current temperature coefficient measurements', in 2015 IEEE 42nd Photovoltaic Specialist Conference (PVSC), New Orleans, LA, 2015, pp. 1-6, https://doi.org/10.1109/PVSC.2015.7355842.

24. A. Pavgi, 'Temperature coefficients and thermal uniformity mapping of PV modules and plants', Master Thesis, Arizona State University, Tempe, AZ, 2016.

25. J. Zhao, A. Wang, S. J. Robinson, and M. A. Green, 'Reduced temperature coefficients for recent high-performance silicon solar cells', Progress in Photovoltaics: Research and Applications, vol. 2, no. 3, pp. 221-225, Jul. 1994, https://doi.org/10.1002/pip.4670020305.

26. M. A. Green, 'Solar cell fill factors: General graph and empirical expressions', Solid-State Electronics, vol. 24, no. 8, pp. 788-789, Aug. 1981, https://doi.org/10.1016/0038-1101(81)90062-9.

27. E. Skoplaki and J. A. Palyvos, 'Operating temperature of photovoltaic modules: A survey of pertinent correlations', Renewable Energy, vol. 34, no. 1, pp. 23-29, Jan. 2009, https://doi.org/10.1016/j.renene.2008.04.009.

28. International Electrotechnical Commission, 'IEC 60891:2009 - Photovoltaic devices - Procedures for temperature and irradiance corrections to measured I-V characteristics', International Standard, 2009.

29. International Electrotechnical Commission, 'IEC 61851-1:2011 - Photovoltaic (PV) module performance testing and energy rating - Part1: Irradiance and temperature performance measurements and power rating', International Standard, 2011.

30. D. C. Jordan, S. R. Kurtz, K. VanSant, and J. Newmiller, 'Compendium of photovoltaic degradation rates: Photovoltaic degradation rates', Progress in
Photovoltaics: Research and Applications, vol. 24, no. 7, pp. 978-989, Jul. 2016, https://doi.org/10.1002/pip.2744.

31. D. C. Jordan, T. J. Silverman, J. H. Wohlgemuth, S. R. Kurtz, and K. T. VanSant, 'Photovoltaic failure and degradation modes: PV failure and degradation modes', Progress in Photovoltaics: Research and Applications, vol. 25, no. 4, pp. 318-326, Apr. 2017, https://doi.org/10.1002/pip.2866.

32. T. Curtis et al., 'Temperature coefficient of power (Pmax) of field aged PV modules: impact on performance ratio and degradation rate determinations', in Reliability of Photovoltaic Cells, Modules, Components, and Systems X, San Diego, United States, 2017, p. 22, https://doi.org/10.1117/12.2281840.

33. J. Kurnik, M. Jankovec, K. Brecl, and M. Topič, 'Development of outdoor photovoltaic module monitoring system', Informacije MIDEM, vol. 38, no. 2, pp. 75-80, 2008.

34. H. Ibrahim and N. Anani, 'Variations of PV module parameters with irradiance and temperature', Energy Procedia, vol. 134, pp. 276-285, Oct. 2017, https://doi.org/10.1016/j.egypro.2017.09.617.

35. Y. Riesen, M. Stuckelberger, F.-J. Haug, C. Ballif, and N. Wyrsch, 'Temperature dependence of hydrogenated amorphous silicon solar cell performances', Journal of Applied Physics, vol. 119, no. 4, p. 044505, Jan. 2016, https://doi.org/10.1063/1.4940392.

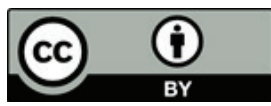

Copyright (c) 2019 by the Authors. This is an open access article distributed under the Creative Commons Attribution (CC BY) License (https://creativecommons.org/licenses/by/4.0/), which permits unrestricted use, distribution, and reproduction in any medium, provided the original work is properly cited.

Arrived: 19. 11. 2019

Accepted: 08. 01. 2020 